November 2017

\title{
Examining Justice in Social Studies Research
}

J. Spencer Clark

Kansas State University

Steven P. Camicia

Utah State University

Follow this and additional works at: https://newprairiepress.org/piper

Part of the Curriculum and Social Inquiry Commons, Educational Methods Commons, and the Gender Equity in Education Commons

\section{Recommended Citation}

Clark, J. S., \& Camicia, S. P. (2017). Examining Justice in Social Studies Research. Pedagogy \&

(Im)Possibilities across Education Research (PIPER), 1 (1). https://doi.org/10.4148/2576-5795.1004

This Article is brought to you for free and open access by New Prairie Press. It has been accepted for inclusion in Pedagogy \& (Im)Possibilities across Education Research (PIPER) by an authorized administrator of New Prairie Press. For more information, please contact cads@k-state.edu. 


\title{
Examining Justice in Social Studies Research
}

\author{
Abstract \\ Our article is an extension of a project involving a content analysis of two social studies journals, Theory \\ and Research in Social Education (TRSE) and The Social Studies. We performed an analysis on all articles \\ in these journals from 2006-2016. Our findings from the analysis indicated a narrow frame of \\ perspectives related to epistemologies and methodologies, and an increasing interest in examining a \\ range of researcher and participant positionalities. We interpreted the range of perspectives in social \\ studies journals in light of the possible impact upon democratic education and social justice through \\ Sen's (2009) framework for theorizing justice. We illustrate aspects of this framework by presenting \\ positionality and autoethnography as methods for increasing epistemologies and perspectives in social \\ studies education and research. \\ Concepts, Ideas, People \\ Positionality, Autoethnography, Justice, Amartya Sen, Social Studies Education \\ Epistemologies, Methods, and Theories \\ Content Analysis, Poststructuralism, Critical Pragmatism
}


For over a century, the purpose and substance of social studies education has been under intense scrutiny (Evans, 2004). Scholars have long attempted to frame the nature of the social studies by placing it within specific categories, through, for example, various legal and political approaches, by traditional curriculum designs, and by emphasizing focus on traditional subjects such as history (Oliver \& Shaver, 1966; Butts, 1988; Crabtree, 1989). Many contemporary scholars have employed counter approaches - non-categorized, critical and more deliberative approaches to the same subject matter, often as a means to increase the inclusiveness and diversity of the curriculum (e.g. Camicia, 2016; Schmidt, 2010; Loutzenheiser, 2006; Dilworth, 2006). Social studies educational research resembles the larger social studies field with competing conceptions of what should be the focus and purpose of its perspectives, for developing and furthering the knowledge of the field. Since the social studies comprise several different social science disciplines, which all have their own inquiry and methodological traditions, the field as a whole often gravitates to broad foci and purposes that can link the disciplines in purpose, such as multicultural education or social justice education. In this article, we will examine social studies education research methodologies through a lens of justice to analyze the field's broad foci and purposes as demonstrated through its publications. From this analysis, we will draw upon an ethics of recognition to offer several ways for social studies education research to better address injustices, as a field, through our research.

As social studies teacher educators and researchers, we are deeply invested in the current trends and future directions of our field, especially in working toward justice. We examined Theory \& Research in Social Education (TRSE) and The Social Studies (TSS) to help us develop a theoretical framework related to the increasing justice in social studies curriculum and research. The choice of TRSE and The Social Studies was not meant to be representative of the entire field of journals but provide only a snapshot of two prominent journals in social studies. We chose TRSE because it is the affiliated research journal with NCSS and CUFA. After his analysis of TRSE issues from 1973 to 1997, Ehman (1998) noted that "TRSE is used as a source of trends in social studies education inquiry over the past 25 years" (p. 238). We chose The Social Studies because it represents a blend of articles on research and practice. We analyzed our findings related to the range of perspectives in social studies journals through the lens of Amartya Sen's (2009) theory of justice to consider the generative purpose of the methodologies and perspectives for furthering justice and/or retreating injustices in social studies education. Using Sen's framework, we identified significant trends within the social studies educational research community as reflected in the two journals. From these trends, we asked, what do the illustrations from our field, as indicated by analysis of top journals, tell us about our field's orientation toward justice?

We used Sen's (2009) theory of justice to analyze social studies research methodologies because of his inductive approach. As an influential and world-renown economist, Sen has consistently confronted modern theories, as well as the roles of institutions in society. His theory of justice departs from top-down notions of purpose that define justice and reimagine a purpose for research 
in which justice is defined by a wide range of positionalities and perspectives from participants in research. Sen's approach toward justice is imbued with a respect for context, focused on the present, and real-world situations in which injustice may exist. His approach allowed us to think about ways of making social studies research a means for shaping justice, instead of exemplifying or illustrating established definitions of justice.

We interpreted our content analysis findings within the context of Sen's (2009) approach. Our content analysis provided a basis for identifying the implications of Sen's theory of justice for social studies educational research. His approach prominently defines a theory of justice that attends well to Cochran-Smith's (2009) teacher education framework that emphasizes the need for both distribution and recognition of justice, instead of only distribution by institutions (see Cochran-Smith (2009) for full articulation of the framework). We paid particular attention to the spaces created for students', teachers', and researchers' positionalities as elements of justice and relational ethics to increase recognition. We also find autoethnography to be a responsive example of methodology that fosters these spaces in social studies classrooms and educational research. For example, Méndez (2013) wrote, "Through reading a cultural or social account of an experience, some may become aware of realities that have not been thought of before, which makes autoethnography a valuable form of inquiry" (p. 282). By valuing these accounts from a variety of positionalities and perspectives, we propose that social studies education can become more inclusive, democratic, and just. In this way, the experiences of individuals form the basis for inquiry from different disciplinary lenses, and social justice based upon experiences becomes the point of departure and return for social studies.

The popular need to move toward increasing perspectives in social studies educational research is illustrated by attention to the ways that instructional materials and curriculum frameworks exclude positionalities and perspectives from the curriculum. The following provide illustrations of exclusions or misrepresentations that serve to reinforce social inequalities. Brown and Brown (2010) found that the $5^{\text {th }}$ and $8^{\text {th }}$ grade U.S. history textbooks' "representations fall short of adequately illustrating how racial violence operated systematically to oppress and curtail African Americans' opportunities and social mobility in the United States," and this failure of "limited representation of racial violence has an adverse effect on the larger sociocultural memory and sociocultural knowledge available to students, thus limiting the extent to which all students can truly understand the historical significance of racial inequities" (p. 150). In their analysis of U.S. history standards in four states, Anderson and Metzger (2011) write, that the standards represented an overly simplistic view of history that failed "to consider that attitudes about slavery existed on a continuum at the time and that slavery was a deeply entrenched economic, political, and social institution and not just a moral failing on the part of individuals." (p. 407). In his examination of Support Documents for $11^{\text {th }}$ grade U.S. history courses in South Carolina, Eargle (2016) found "the Support Document does not offer a complete narrative of slavery and African Americans, 
perpetuates a negative image of African Americans, excludes themes of African American heroism, and maintains myths related to slavery" (p. 295). Those who are marginalized in and by the social studies curriculum are unable to find positionality historically, or a sense of identity within the curriculum (Heafner \& Fitchett, 2017; Salinas, 2006; VanSledright, 2002).

The narrow range of perspectives found in these studies serve to bolster an official knowledge and dominate narratives that reinforce social inequalities (Carlson, 2008). The mis/representations found in curriculum standards serve to locate historically marginalized positionalities in the margins of history. Journell (2009) examined the American history standards of nine states. The standards "leave little doubt that each state prescribes to a traditional version of history that identifies American Indians as victims and marginalizes them by failing to identify key individuals or examples of societal contributions" (p. 28). In their analysis of the curriculum standards of 50 states, Shear, Knowles, Soden, and Castro (2015) write that "standards overwhelmingly present Indigenous Peoples in a pre-1900 context and relegate the importance and presence of Indigenous Peoples to the distant past" (p. 68). In her study of U.S history standards, An writes (2016) "The invisibility of the Asian American experience in the official script of U.S. history sends a message that Asian Americans are not legitimate members of this nation and have little place in the story of the United States" (p. 268). The patterns of exclusion found in these studies occur in many forms ranging from classrooms, to instructional materials, to state standards, to national standards. In her examination of the NCSS vision statement and standards, Schmidt (2010) observed that there is a lack of visibility of LGBTQ issues. She proposes increasing the lens of queer theory as an opportunity "to deconstruct the discourse of common good and civic engagement for the implicit ways in which LGBTQ issues may be positioned. Understanding what is normalized allows us to imagine what is necessary to change the discourse of social studies and citizenship" (p. 331).

An examination of positionalities and perspectives should also include attention to intersectionality. Woyshner and Schocker (2015) did a content analysis of high school history textbooks for representations of Black women. They focused their analysis on the intersectionality of race, gender, and class, and they found that Black women are underrepresented in history textbooks. They also found that content analysis needs to consider race, gender, and class as lenses for understanding representation and social studies education in a light that increases perspectives in the curriculum related to intersectionality and the dimensionality of marginalization. While most research on content analysis emphasize that the content of instructional materials and standards is not necessarily indicative of the enacted curriculum, the frameworks that these materials provide can be a strong indicator of the educational objectives of the curriculum. How positionalities and perspectives are represented, misrepresented, or invisible can send powerful messages to educators and students. The purpose of this article is to explore a framework for identifying these injustices through an ethics of recognition. 


\section{Theoretical Perspectives}

\section{Sen's Theory of Justice}

In The Idea of Justice, Sen (2009) offers a theory of justice that serves as a counter to previous philosophical works. Sen's theory of justice is an inductive, comparative process that focuses on the realities of those involved in the quest for justice. This method of determining justice eschews predetermined, universal definitions in favor of bottom-up flexibility that respects context and participants. As a lens for students, teachers, and researchers, this emphasizes multiple perspectives as they relate to deliberation surrounding social issues and social sciences. Sen's argument has three central elements: 1) justice-thinking must be comparative in nature; 2) the recognition of one's identity is vital in the determination of what is just or unjust; and 3) public reasoning can serve as a tool to both advance justice and/or retreat injustices.

First, Sen (2009) argues throughout his work for a new way to advance justice and reduce injustices. As a result, he rejects many of his philosophical predecessors, including John Rawls. In Rawls' (1971) Theory of Justice, he presented a theory of social justice grounded in the traditions of transcendental institutionalism. Rawls used a deductive process and theorized that social justice needed a predetermined, universal definition of justice. Rawls began his theory of justice from an assumption of equality, commonly known by "justice as fairness." Per Rawls' theory of social justice, if humanity assumes perfect equality, elements of justice could be predetermined and agreed upon to form a just, utopian society. Rawls called this the "original position," and from this perspective people would select the type of society they want and shape justice around their ideal. Sen rejects Rawls' view, positing that justice should be viewed as "comparative" in nature. This comparative theory of justice allows individuals to determine the most just resolution to conflicts without a singular, monolithic definition of perfect justice. Sen repeatedly refers to Rawls' method (and similar philosophies) as a transcendental approach, concerned solely with the a priori or intuitive basis of knowledge as independent of experience. Sen counters with his own comparative viewpoint to address what he sees as a more realistic and inclusive form of justice-thinking.

Second, much of Sen's (2009) argument regarding the understanding of one's own identity as a central facet of justice-thinking revolves around his concept of positional objectivity. Positional objectivity involves recognizing how the world looks depends very much on where one is standing in it. Deep moral, philosophical, and religious beliefs (among others) impact one's own view of what is just or unjust in society, and hoping for complete objectivity in these matters is not possible. Instead, Sen argues that objective observations are position-dependent, grounded in what an individual is "able to see from a given position" (p. 158). For example, the social background of a person, rooted in the community and culture in which the person was raised, will determine 
patterns of reasoning and ethics available to them in the determination of what is just. The social circumstances, religious environment and cultural-philosophical context in which an individual is raised creates their identity. In such an instance, the identity of the person, including affiliations to particular groups, naturally influences justice-thinking and makes determinations of justice relative to their context. These differences can be communicated and deliberated through the lenses of geography, sociology, economics, history, civics.

Finally, perhaps the most important facet of Sen's (2009) argument is his method for achieving global justice. Unlike his philosophical predecessors, Sen argues that a theory alone, especially an idealistic one, does little if not supported by a plan capable of being implemented. Grounding his argument in the importance of achieving a kind of global democracy, Sen posits that the demands of comparative justice can be assessed only with the use of public reasoning. Informed deliberation and discourse can be the methods through which injustices around the world are realized and prevented, and Sen's model embraces public reasoning by placing the determinations of justice in the hands and minds of individuals acting as agents rather than institutions.

We use Sen's (2009) theory of justice to analyze the limitations and possibilities of social studies education and research in terms of the comparative and inclusive nature of predominant research epistemologies, the role of researcher positionality, and more democratic and deliberative ways of assessing and disseminating research. We propose recognition of positionality and autoethnography as a way to apply the principles of Sen's theory toward principles of social studies education and research.

\section{Methodology}

In consideration of our own positionality, one author is a White male, heterosexual assistant professor at a large state university. He considers himself a critical pragmatist (Cherryholmes, 1988; Cornbleth \& Waugh, 1995) epistemologically, and his methodological choices include casestudy, action research, content-analysis, and autoethnography. The second author is a White, queer male, associate professor at another large state university. He considers himself a poststructuralist, and his methodological choices range from discourse analysis to autoethnography. We experience social studies education and research through the lenses that result from these positionings. Subjects such as civics, economics, history, and geography are all experienced by us in different ways. As an illustration, rather than attempting to collapse our understandings of an economic or geographical issue into consensus, we strive to use positionality as a lens to better understand how different perspectives can increase our understandings of social justice. The first author's work focuses on how sociocultural aspects enable and constrain individuals mediated action, and he strives to better develop understandings of social studies, such as economics and civics, to enable individuals to achieve agency in their ecological context. The second author's work and 
understandings focus upon how elements of social studies such as economics and geography function discursively. Bodies move through different spaces and discursive fields that serve to privilege or marginalize, and the range of perspectives in social studies curriculum can support or discourage critical democracy. As researchers, we strive to be reflexive in the same way that we are proposing students, educators, and other researchers approach social studies education.

As context for our new work described in this paper, we will briefly describe our prior study. We used content analysis, which calls for systematic examination of textual data (Krippendorff, 2004; Schreier, 2014). After collecting all articles published in the TRSE and The Social Studies from 2006-2016, we identified and consistently applied a predetermined coding schema for the analysis of texts. One third of our codes were based on researcher's methodological choices and utilized a framework developed by Koro-Ljundberg et al. (2009). This involved interpreting categories of theoretical perspectives in articles related to epistemological and methodological orientations. For example, Koro-Ljundberg et al. (2009) identified categories of interpretivist, critical, and pluralists, as well as related categories such as constructionism, poststructuralism, and hybrid perspectives. The other two-third of the codes were focused on the articles' content. These included a coding frame with aspects of social studies education such as the grade levels that the articles were aimed toward, the subject areas such as geography or civics, and topics such as deliberation. We used content analysis to guide the description, analysis, and interpretation of data. The six members of our research team developed a matrix for coding articles. Each year of each issue had two people coding the journals independently of each other. The entire research team met to discuss any inconsistencies between the analyses of team members. The primary goal of these meetings was not to come to a consensus but gain a deeper understanding of the content analysis through dialogical methodology. Based upon our analyses and conversations we modified our coding schema in order to reduce redundancies in codes and reflect emergent relationships between codes. For this manuscript, we focused our analysis on the codes related to researchers' methodological choices.

\section{Findings}

From our analysis of social studies education research journals, the findings in regard to research epistemologies and methodologies demonstrate a narrow orientation to justice, and these findings relate to the three tenets of Sen's (2009) theory of justice. First, the studies and articles in these two journals overwhelmingly fall within the theoretical perspective related to post-positivism and ethnography. From Sen's comparative standpoint, social studies research is very limited in its theoretical perspectives and epistemologies. The limited theoretical perspectives and epistemologies in the field of social studies also limit potential for comparative views of the same or similar injustices. While post-positivist and ethnographic methods are inductive in their approach, they fail to prioritize the researcher's relational positions in developing new knowledge. 
These relational positions as they relate to positionalities and related epistemologies are often subsumed by efforts to gain consensus. Post-positivist concepts of triangulation emphasize consensus of perspectives as a measure of validity. This failure to prioritize relational positions represents a failure to analyze the power relations in our research and work, and ultimately, this leads to research decisions, knowledge production, and methods of teaching that are decontextualized from the places of in/justice we are researching. This is problematic in consideration of Sen's theory of justice, especially in a democratic sense, because without multiple theoretical perspectives or epistemologies, power relations that result in injustices cannot be addressed without comparative relational positions to consider. In other words, narrow epistemological expressions in research restrict expression in ways that are anti-democratic and unjust.

Second, even when theoretical perspectives outside of the post-positivist perspective are utilized in social studies research, such as feminism, poststructuralism, and postcolonialism, the methodological junctures are often more reflective of post-positivist perspectives. For example, one of the key components of feminist and postcolonial perspectives is to address the positionality of the researcher. The articles, within any of the paradigms represented in the data, rarely addressed researcher positionality ( 5 articles, 1 in TSS and 4 in TRSE) and reflexivity. This is significant because positionality is influential upon aspects of research projects ranging from the development of a research interest and questions to the analysis and interpretation of data. In consideration of identity, and Sen's (2009) concept of positional objectivity, social studies education research has failed to prioritize the positionalities of the researchers, and potentially the positionalities of the participants, in developing new conceptions of justice. Sen, and others, would argue this discounts the agency of individuals in their struggle to highlight justice and retreat injustices. When positionality, or positional objectivity, is ignored, then developments of justice can easily be attributed to structural or institutional forms of justice that Sen refers to as transcendental.

Third, the trend of using critical perspectives and epistemologies has increased in social studies education. These findings are significant because they illustrate the gradual shift in the theoretical orientations of the social studies educational research community. The use of these orientations represents a shift from a narrow range of dominant epistemologies and interests that are not representative of democratic inclusion and justice within social studies educational research. From the public reasoning standpoint, social studies education research must find new ways to encourage researchers to engage in a wider variety of methodologies, and to develop more inclusive and flexible assessments and perspectives on justice. The data demonstrates that on some level postpositivist methods and terminology have been reinforced through their acceptance in the review process, while critical methods have generally been subjected to more scrutiny, and potentially rejected. An openness to critical methods is necessary to evolve these methodologies with the 
issues of the field. The more that new methodologies are used, reviewed, and reasoned over, the better developed these methods will become in the field of social studies education.

Our perspective is that the constraints related to a narrow range of epistemological perspectives in research work to subsume differences that exists in students and educators. When applied to social studies education, a conscious effort to examine social studies education through a wide range of perspectives will create a more inclusive picture of how students and teachers experience knowledge and disciplines.

\section{Implications}

We think social studies educational research can better address injustices in two key ways. We think a primary goal for all social studies educational research, regardless of the epistemological or theoretical perspective, is to have a well-articulated researcher positionality. Positionality is necessary for understanding the researcher's power relations to the participants, context, and knowledge being produced. Prioritizing positionality in social studies research, very simply, tells the reader what the author is positioned to know and not know. Prioritizing positionality invites authors "to acknowledge our own power, privilege, and biases just as we denounce the power structures that surround our subjects" (Madison, 2011). Awareness and acknowledgement of one's position to know, or not know, better enables researchers to retreat injustices in relation to Sen's (2009) theory. In this way, we have outlined three components of articulating one's positionality to retreat injustices in the field of social studies, initial questions for researchers to think about, and implications for students and educators as they experience curriculum.

First, comparative positionality, highlights the need for researchers to be aware of, and acknowledge, their own positionality before they can think of justice comparatively, or even be critical in their assessment of their own power, privilege, and biases. Comparative positionality also requires one to think about the similarities of their positionality to other researchers who have addressed similar injustices. It asks researchers to apply an ethics of recognition in their research and consideration of their implications. Researchers should ask themselves: How is my research enabled by the field of social studies? How is my research constrained by the field of social studies? These questions are important because they can reveal the degree of power, privilege, and biases to which our research is positioned within the field. Students and teachers can engage with social issues by asking how they are related to issues of social justice. How do differently positioned students and teachers understand issues of social justice? What aspects of power and privilege constrain perspectives of inquiry within the social studies curriculum?

Second, positionality as objectivity, acknowledges our position and recognizes that our positionality is shifting and not static. Recognizing this shift is important for our research 
implications because if we truly acknowledge the role of our positionality in our research, then our research will inevitably influence our positionality in our future research projects and agenda. As researchers, our research inevitably shifts our positionality, however, awareness and acknowledgment of our positionality, as well as any shifts, further validates our knowledge and understanding of our work. In this way, positionality as objectivity relies upon situated knowledge and mediated action to develop opportunities for deeper meaning-making. Researchers should ask themselves: How has my research shifted my positionality? How has my research reaffirmed my positionality? Students and teachers can examine the nature of knowledge, 'truth', and power within different areas of the social studies curriculum.

Third, positionality as reasoning, acknowledges that our positionality is one of many in the field of social studies education research. From a pragmatist view, our field benefits from many individuals deeply thinking about and researching ways of solving a problem or injustice. Furthermore, our field depends upon research that raises corresponding questions for the rest of the field, to build upon the knowledge base. We approach this, as a field, partly by outlining implications for our research; however, implications fall short in terms of positionality as reasoning. In addition to outlining the implications of findings for the field, we need to outline the implications of our experiences researching for the field. If we are going to holistically work toward retreating injustices as a field, then we need to be clear and directive about all aspects of our research. Researchers should ask themselves: How does this research experience, analyzed through my positionality, generate corresponding work in the field of social studies? How is this research experience, analyzed through my positionality, limited/narrow in its scope within the field of social studies? What positionalities or perspectives would further generate meaning based on this research experience? These questions are important because they highlight the importance of the research experience, not just the research findings, to expand awareness of the relational aspects of the field. Positionality as reasoning emphasizes deliberation which emphasizes an increase in perspectives surrounding social issues. Students and teachers can use this deliberative approach in inquiry with disciplinary lenses within the curriculum.

\section{Autoethnography}

Autoethnography is a methodology that places positionalities and related epistemologies as lenses for understanding how power relations function. Individuals are located within networks of power relations that are responsible for social injustices. In autoethnography, students or researchers are able to examine their experiences and positionalities in order to better understand how power relations function in society (Adams, 2011; Camicia, 2016; Jones, 2005; Spry, 2006). Positionality is central to understanding an ethics that is relational. Maher and Tetreault (1993) write:

Gender, race, class, and other aspects of our identities are markers of relational positions rather than essential qualities. Knowledge is valid when it includes an acknowledgment of 
the knower's specific position in any context, because changing contextual and relational factors are crucial for defining identities and our knowledge in any given situation. (p. 118)

Autoethnography increases the range of perspectives and epistemologies in research and beyond by placing knowledge/power relations as central to reasoning. The three elements of Sen's (2009) theory of justice align well with our focus upon autoethnography in these ways: 1) justice-thinking must be comparative in nature. Autoethnography provides opportunities for understanding power relations between individuals. Rather than individuals being subsumed in a false notion of neutrality, justice can only be achieved if inequitable power relations are examined in public reasoning; 2) the recognition of one's identities is vital in the determination of what is just or unjust. Autoethnography places an ethics of recognition of identities as central to the process of addressing social inequalities (Camicia, 2014); and 3) public reasoning can serve as a tool to both advance justice and/or retreat injustices. By placing positionality as the center of any deliberations of justice (e.g. Young, 2000), autoethnography provides the basis to advance justice through reasoning on the consensus of individuals' experiences, and not the history of individual experiences in the system. These deliberations connect the variety of human experiences to a variety of ways of knowing and social studies disciplines.

We also think that autoethnography should be prioritized and valued more in social studies educational research. The implications for the design and implementation of curriculum involve an expanded awareness of inclusion, democracy, and social justice. Through this approach, students and educators can understand their experiences as relational through the tools of inquiry of social studies disciplines. The examination and deliberation of social issues from this perspective takes seriously the realities of inequitable power relations within curriculum. This points to the ways that power shapes knowledge and 'truths'. Such learning experiences and the methodologies to interpret them provide a more responsive way to understand an increasingly hybridized world where the subsumption of knowledge in a dominant narrative is unjust. Sen's (2009) approach to justice provides the themes necessary to guide these experiences.

\section{Closing Thoughts}

Sen's (2009) argument provides the opportunity to envision social studies research transformed. By exploring the fundamental arguments of Sen's idea of justice and its relation to social studies research, we, as educational researchers, are compelled to reconsider the theoretical basis for our research, as well as question the rationale behind each method chosen. Ultimately, Sen's vision of justice cannot serve as the singular guide for how social studies research can, or arguably should, be more just or address injustices. Rather, the elements of Sen's justice, including the uncovering and retreat of injustices, should serve to remind us that complexity and tradition are not suitable reasons for a harmful act to continue to occur. Answers to social justice are neither universal, nor 
easily obtained. But the way in which justice is established, whether it is through an understanding and appreciation of human rights, civic responsibility, or faith, is imperative for the continued and sustained success of our democratic culture.

Through our previous study, we found a narrow range of epistemological perspectives and an even narrower range of methodological perspectives within the journals that we examined. We conclude that this has large implications for social studies curriculum. The ways of knowing, deliberating, and experiencing social issues could be expanded toward recognition and social justice if the epistemological and methodological stances in social studies curriculum and research are expanded. 


\section{References}

Adams, T. E. (2011). Narrating the closet: An autoethnography of same-sex attraction. Walnut Creek, CA: Left Coast Press, Inc.

An, S. (2016). Asian Americans in American History: An AsianCrit perspective on Asian American inclusion in state U.S. history curriculum standards. Theory and Research in Social Education, 44(2), 244-276.

Anderson, C. B., \& Metzger, S. A. (2011). Slavery, the Civil War era, and African American representation in U.S. history: An analysis of four states' academic standards. Theory and Research in Social Education, 39(3), 393-415.

Brown, K. D., \& Brown, A. L. (2010). Silenced memories: An examination of the sociocultural knowledge on race and racial violence in official school curriculum. Equity \& Excellence in Education, 43, 139-154. doi: 10.1080/10665681003719590

Butts, R. F. (1988). History and civic education. In B. R. Gifford (Ed.), History in the schools: What shall we teach? (pp. 61-81). New York: Macmillan.

Camicia, S. P. (2014). Navigating/embodying controversy in classrooms in the United States and Philippines: Using autoethnography to understand the complexities of democracy in different contexts. In T. Misco \& J. De Groof (Eds.), Cross-cultural case studies of teaching controversial issues: Pathways and challenges to democratic citizenship education (pp. 95-109). Oisterwijk, Netherlands: Legal Wolf Publishers.

Camicia, S. P. (2016). Critical democratic education and LGBTQ-inclusive curriculum: Opportunities and constraints. New York: Routledge.

Carlson, D. (2008). Remembering Rosa: Rosa Parks, multicultural education, and dominate narratives of the Civil Rights Movement. In Susan Schramm-Pate and Rhonda B. Jeffries (eds.) Grappling with Diversity. Albany, NY: State University of New York Press.

Cherryholmes, C. H. (1988). Power and criticism poststructural investigations in education. NY: TC Press.

Cochran-Smith, M. (2009). Toward a theory of teacher education for social justice. In A. Hargreaves, A. Lieberman, M. Fullan, \& D. Hopkins (Eds.), Second international handbook of educational change (Vol. 23, pp. 445-467). New York: Springer.

Crabtree, C. (1989). Returning history to the elementary schools. In P. Gagnon and the Bradley Commission on History in the Schools (Eds.), Historical literacy: The case for history in American education (pp. 173-187). Boston: Houghton Mifflin.

Denzin, N. K. (2012). Triangulation 2.0. Journal of Mixed Methods Research, 6(2), 80-88.

Dilworth, P. P. (2006). Widening the circle: African American perspectives on moral and civic learning. In D. Warren \& J. J. Patrick (Eds.), Civic and moral learning in America (pp. 103-118). New York: Palgrave Macmillan.

Eargle, J. C. (2016). The dominant narrative of slavery in South Carolina's history standards. The Journal of Social Studies Research, 40, 295-307. 
Ehman, L. H. (1998). Trends in Theory and Research in Social Education from 1973-1997: Implications for goals and process. Theory and Research in Social Education, 26(2), 238257.

Evans, R. (2004). The social studies wars: What should we teach the children? New York: Teacher's College Press.

Heafner, T. L., \& Fitchett, P. G. (2017). US history content knowledge and associated effects of race, gender, wealth, and urbanity: Item Response Theory (IRT) modeling of NAEP-USH achievement. The Journal of Social Studies Research.

Jones, S. H. (2005). Autoethnography: Making the personal political. In N. K. Denzin \& Y. S. Lincoln (Eds.), The SAGE handbook of qualitative research (3rd ed., pp. 763-791). Thousand Oaks: Sage Publications.

Journell, W. (2009). An incomplete history: Representation of American Indians in state social studies standards. Journal of American Indian Education, 48(2), 18-32.

Klesse, C. (2010). Teaching on 'race' and ethnicity: problems and potentialities related to 'positionality' in reflexive and experiential approaches to teaching and learning. Enhancing Learning in the Social Sciences, 2(3), 1-27.

Koro-Ljungberg, M., Yendol-Hoppey, D., Smith, J. J., \& Hayes, S. B. (2009). (E)pistemological awareness, instantiation of methods, and uniformed methodological ambiguity in qualitative research projects. Educational Researcher, 38(9), 687-699.

Krippendorff, K. (2004). Content analysis: An introduction to its methodology (2nd ed.). Thousand Oaks, CA: Sage Publications.

Loutzenheiser, L. W. (2006). Gendering social studies, queering social education. In A. Segall, E. E. Heilman, \& C. H. Cherryholmes (Eds.), Social studies: The next generation (pp. 61-75). New York: Peter Lang.

Madison, D. S. (2011). Critical ethnography: Method, ethics, and performance. Sage.

Maher, F. A., \& Tetreault, M. K. (1993). Frames of positionality: Constructing meaningful dialogues about gender and race. Anthropological Quarterly, 118-126.

Méndez, M. (2013). Autoethnography as a research method: Advantages, limitations, and criticisms. Columbian Applied Linguistics Journal, 15(2), 279-287.

Oliver, D. W., \& Shaver, J. P. (1966). Teaching public issues in the high school. Boston: Houghton Mifflin.

Rawls, J. (1971). A theory of justice. Cambridge, MA: Harvard University Press.

Ross, E. W. (Ed.). (2014). Social Studies Curriculum: Purposes, Problems, and Possibilities. SUNY Press.

Salinas, C. (2006). Educating late arrival high school immigrant students: A call for a more democratic curriculum. Multicultural Perspectives, 8(1), 20-27.

Schreier. (22014). Qualitative content analysis. In U. Flick (Ed.), The SAGE handbook of qualitative data analysis (pp. 170-184). London: SAGE Publications Ltd.

Schmidt, S. J. (2010). Queering social studies: The role of social studies in normalizing 
citizens and sexuality in the common good. Theory and Research in Social Education, 38, 314-335.

Sen, A. (2009). The idea of justice. Cambridge, MA: The Belknap Press of Harvard University Press.

Shear, S. B., Knowles, R. T., Soden, G. J., \& Castro, A. J. (2015). Manifesting destiny: $\mathrm{Re} /$ presenting of indigenous peoples in K-12 U.S. history standards. Theory and Research in Social Education, 43(1), 68-101.

Spry, T. (2006). Performing autoethnography: An embodied methodological praxis. In S. N. Hesse-Biber \& P. Leavy (Eds.), Emergent methods in social research (pp. 183-211). Thousand Oaks, CA: Sage Publications.

VanSledright, B. (2002). Confronting history's interpretive paradox while teaching fifth graders to investigate the past. American Educational Research Journal, 39(4), 1089-1115.

Woyshner, C., \& Schocker, J. B. (2015). Cultural parallax and content analysis: Images of Black women in high school history textbooks. Theory and Research in Social Education, 43(4), 441-468.

Young, I. M. (2000). Inclusion and democracy. New York: Oxford University Press. 